\title{
IMPLEMENTASI PENDIDIKAN KARAKTER BERBASIS PESANTREN DI MADRASAH
}

\author{
Sigit Priatmoko \\ Fakultas Agama Islam Universitas Islam Darul 'Ulum Lamongan \\ Jl. Airlangga No. 03 Sukodadi Lamongan \\ Email: sigitpriatmoko@gmail.com
}

\begin{abstract}
Abstrak
Dinamika perkembangan pendidikan di Indonesia selalu diwarnai dengan berbagai problematika laten yang sampai sekarang terus menjadi pekerjaan rumah bersama. Problematika tersebut terkait dengan sistem pendidikan, kurikulum, kualitas lulusan, profesinoalitas, kesejahteraan dan integritas pendidik, infrastruktur, biaya, serta akuntabilitas lembaga dan pengelola pendidikan. Selain permasalahan tersebut, pendidikan kita juga dihadapkan dengan permasalahan dekadensi moral generasi muda. Satu di antara penyebab masalah ini adalah masih kurang optimalnya lembaga pendidikan dalam menjalankan perannya. Lembaga pendidikan di Indonesia dinilai terlalu memberikan porsi yang sangat besar untuk transmisi pengetahuan, namun kurang bahkan melupakan pengembangan sikap, nilai dan perilaku dalam pembelajaran. Demikian juga dalam proses evaluasi, dimensi kognitif menjadi tolok ukur utama untuk menentukan tingkat prestasi peserta didik. Akibatnya, lembaga pendidikan mampu menghasilkan lulusan yang mempunyai pengetahuan luas namun kurang mempedulikan lingkungan sosial di sekitarnya. Ironisnya praktek pendidikan ini juga berlangsung di madrasah yang notabene merupakan lembaga pendidikan Islam. Madrasah seharusnya mencontoh upaya-upaya yang dilakukan pesantren dalam hal menanamkan karakter, yakni melalu pendekatan keteladanan, pembiasaan, pendisiplinan, proses pembelajaran dan pengintegrasian dalam materi pelajaran.
\end{abstract}

Kata Kunci: Nilai-nilai Karakter, Pesantren, Belajar Mengajar, Madrasah

\section{A. Pendahuluan}

Dinamika perkembangan pendidikan di Indonesia selalu diwarnai dengan berbagai problematika laten yang sampai sekarang terus menjadi pekerjaan rumah bagi bangsa ini. Problematika tersebut terkait dengan sistem pendidikan, kurikulum, kualitas lulusan, profesinoalitas, kesejahteraan dan integritas pendidik, infrastruktur, biaya, serta akuntabilitas lembaga dan pengelola pendidikan. 
Selain problematika tersebut, dunia pendidikan Indonesia juga sedang dihadapkan dengan permasalahan dekadensi moral yang melanda peserta didik. Nilainilai luhur bangsa seperti kesopanan, keramahan, tenggang rasa, rendah hati, suka menolong, solidaritas dan sebagainya semakin memudar di kalangan generasi muda. Kondisi ini semakin diperparah dengan kondisi lingkungan sosial yang tidak lagi representatif sebagai tempat belajar bagi mereka. Hilangnya keteladanan pemimpin, sering terjadinya pembenaran politik dalam berbagai permasalahan yang jauh dari kebenaran universal, dan larutnya semangat berkorban bagi bangsa dan negara adalah sederet fenomena yang akrab di telinga generasi muda.

Terjadinya krisis moral tersebut sebagian bersumber dari masih kurang optimalnya lembaga pendidikan dalam membentuk kepribadian peserta didik. Lembaga pendidikan kita dinilai terlalu memberikan porsi yang sangat besar untuk transmisi pengetahuan, namun kurang bahkan melupakan pengembangan sikap, nilai dan perilaku dalam pembelajaran. Dan dimensi sikap juga tidak menjadi komponen penting dalam proses evaluasi pendidikan. Hal demikian terjadi karena model penilaian yang berlaku untuk beberapa mata pelajaran yang berkaitan dengan pendidikan nilai selama ini hanya mengukur kemampuan kognitif peserta didik. ${ }^{1}$

Orientasi pendidikan yang cenderung mengedepankan pengembangan dimensi kognitif dan abai terhadap pengembangan dimensi afektif akan menciptakan ketimpangan antara kematangan intelektual dan kematangan pribadi. Peserta didik akan mempunyai pengetahuan luas namun kurang memiliki sistem nilai yang menjadi pedoman untuk berperilaku. Sebagai akibatnya, ia akan mudah terseret ke dalam praktik penyimpangan moral karena sistem nilai yang seharusnya menjadi patokan dalam berperilaku belum tertanam kuat di dalam dirinya. Sehingga pada akhirnya, pendidikan akan melahirkan lulusan spesialis yang kering nilai dan kurang peduli dengan lingkungan sekitarnya.

Pendidikan model ini menempatkan peserta didik dan guru dalam ketidakberdayaan. Peserta didik— terutama ketika mendekati ujian nasional—setiap hari

\footnotetext{
${ }^{1}$ Masykuri Bakri, Wajah Baru Pendidikan, hlm 34.
} 
“dicekoki” berbagai macam soal yang diprediksi akan muncul dalam ujian. Mereka harus sanggup menampung hafalan teori dan rumus yang ditransfer oleh guru jika ingin lulus ujian. Guru terpaksa berbuat demikian karena tuntutan untuk menjaga gengsi dan citra sekolah.

Guru di kelas terakhir sering kali menempuh berbagai cara agar siswanya bisa lulus dengan prestasi yang baik; entah dalam bentuk les, pemadatan materi, atau drill soal-soal. Semakin banyak "dicekoki" soal-soal Ujian Nasional tahun sebelumnya, siswa dianggap dalam kondisi "siap tempur” menghadapi Ujian Nasional. Tak ayal lagi, suasana pembelajaran semacam itu semakin jauh dari nilai-nilai edukatif dan semakin kering dari sentuhan problem-problem sosial yang mestinya "dibumikan" dan diakrabkan dalam dunia peserta didik. Bahkan, praktik pendidikan semacam semacam itu dinilai sangat bertentangan dengan tujuan diselenggarakannya pendidikan formal di negara mana pun karena akan menyebabkan terjadinya proses penyempitan kurikulum (curriculum contraction). ${ }^{2}$

Ironisnya, praktik pendidikan semacam ini juga terjadi di madrasah yang notabene merupakan lembaga pendidikan bernafaskan Islam. Madrasah seharusnya lebih memprioritaskan internalisasi nilai daripada pengembangan aspek kognitif semata. Proses pendidikan di madrasah haruslah berbeda dengan sekolah umum. Kegiatan belajar mengajar di madrasah harus diposisikan sebagai proses penggemblengan untuk "mematangkan" kepribadian peserta didik menuju manusia yang sempurna (insan kamil) yaitu manusia yang matang profesionalitas dan spiritualitasnya. Maka konsekuensinya, kegiatan belajar mengajar di madrasah harus berbasis pada nilai-nilai karakter.

Pembelajaran yang berbasis pada internalisasi nilai-nilai karakter lebih menekankan pada praktik pengamalan nilai-nilai luhur di setiap aktivitas belajar daripada hanya hafalan konsep. Misalnya pada mata pelajaran Aqidah Akhlak pada materi tentang sifat-sifat terpuji, kegiatan belajar mengajar harus disertai praktik pengamalan sifat-sifat terpuji dan ditambah dengan keteladanan guru. Penilaian juga

\footnotetext{
${ }^{2}$ Masykuri Bakri, Membumikan Nilai Karakter Berbasis Pesantren Belajar dari Best Practice Pendidikan Karakter Pesantren dan Kitab Kuning, (Jakarta: Nirmana Media, 2011), 37
} 
harus mengacu pada seberapa jauh peserta didik mampu mengamalkan sifat-sifat terpuji tersebut. Sehingga peserta didik tidak hanya mengetahui konsep sifat-sifat terpuji akan tetapi telah mengamalkannya dalam kehidupan sehari-hari. Dalam hal ini madrasah bisa mencontoh apa yang telah dilakukan pesantren. Mengapa pesantren? Hal ini karena pendidikan di pesantren sangat menekankan aspek keteladanan dari para asâtidz terutama dari tokoh sentral di pesantren yaitu kyai. Model penanaman karakter ini terbukti efektif dari masa ke masa dan telah menjadi bagian dari entitas pesantren itu sendiri.

Tulisan ini mencoba menawarkan sebuah alternatif solusi yang dapat digunakan madrasah tidak hanya untuk memperkuat eksistensinya namun juga untuk meningkatkan kualitas lulusannya. Solusi tersebut adalah dengan melakukan internalisasi nilai-nilai karakter berbasis pesantren ke dalam setiap kegiatan belajar mengajar. Nilai-nilai karakter seperti sopan santun, ramah, gotong royong, tawadlu', dan sebagainya yang mulai memudar di kalangan peserta didik perlu direvitalisasi. Sehingga lulusan Madrasah diharapkan tidak hanya memiliki kematangan profesionalitas namun juga memiliki kematangan spiritualitas.

\section{B. Konsep Dasar Pendidikan Karakter}

\section{Pengertian Pendidikan Karakter}

Dalam beberapa bahasa, secara harfiah karakter memiliki berbagai arti seperti: "kharacter" (Latin) yang berarti instrument of marking, "charessein" (Prancis) yang berarti to engrove (mengukir), "tabi'at" (Arab) yang berarti watak, "watek" (Jawa) yang berarti ciri wanci, watak (Indonesia) yang berarti sifat pembawaan yang mempengaruhi tingkah laku, budi pekerti, tabiat, dan perangai. Dalam Kamus Besar Bahasa Indonesia (KBBI), karakter adalah sifat, kejiwaan, akhlak, budi pekerti yang membedakan seseorang dengan orang lain. ${ }^{3}$

Karakter merupakan nilai-nilai perilaku manusia yang berhubungan dengan

Tuhan Yang Maha Esa, diri sendiri, sesama manusia, lingkungan, dan kebangsaan

\footnotetext{
${ }^{3}$ Masykuri Bakri, Membumikan Nilai, 1
} 
yang terwujud dalam pikiran, sikap, perasaan, perkataan, dan perbuatan berdasarkan norma-norma agama, hukum, tata krama, budaya, dan adat istiadat. ${ }^{4}$

Berdasarkan pengertian di atas, dapat dipahami bahwa karakter sangat erat kaitannya dengan kepribadian suatu individu. Seseorang bisa disebut berkarakter manakala tingkah lakunya sesuai dengan prinsip-prinsip moral yang berlaku di masyarakat. Karakter merupakan ciri khas seseorang, masyarakat, atau suatu bangsa yang membedakan ia dengan orang, masyarakat, atau bangsa lain. Bangsa Indonesia dikenal di mata dunia sebagai bangsa yang memiliki karakter sopan, ramah, santun, suka menolong, egaliter dan sebagainya. Karakter ini telah melekat dalam diri bangsa Indonesia dan telah mengakar kuat di setiap diri bangsa Indonesia. Sehingga jika terdapat tingkah laku seseorang yang tidak mencerminkan karakter tersebut maka perlu dipertanyakan ke-Indonesia-annya.

Bangsa yang besar adalah bangsa yang memiliki karakter yang mampu membangun sebuah peradaban besar yang kemudian mempengaruhi perkembangan dunia. Nabi Muhammad sebagai manusia sempurna yang pernah hidup di muka bumi telah memberikan contoh keteladanan bagaimana membangun sebuah karakter bangsa dan mempengaruhi dunia. Sehingga Michael H Haert penulis buku 100 tokoh berpengaruh di dunia menempatkan Nabi Muhammad sebagai manusia paling berpengaruh sepanjang sejarah kemanusiaan, karena mampu merubah sebuah wajah karakter masyarakat dari realitas masyarakat yang sangat tidak beradab, suka menyembah patung, suatu produk manusia yang disembahnya sendiri, suka berjudi, suka membunuh para anak perempuannya karena dianggap melemahkan citra diri keluarga besar (suku), memberikan penghargaan atas wanita dengan cara yang sangat murah dan keji, memperjualbelikan manusia dengan sistem perbudakan. Semua realitas itu kemudian dirubah dengan cara yang sangat indah dan cerdas melalui keteladanan dan dibangun karakter masyarakatnya kemudian mampu mempengaruhi karakter bangsanya sehingga dapat diakui dalam

\footnotetext{
${ }^{4}$ Marjuni, Pilar-pilar Pendidikan Karakter Dalam Konteks Keislaman, Auladuna, Vol. 2 No. 1, Juni 2015
} 
percaturan sebuah kawasan (jazirah) bahkan hingga mampu merubah sejarah perjalanan dunia. ${ }^{5}$

Apa yang telah dicontohkan Nabi Muhammad SAW. membuktikan bahwa kematangan intelektual bukanlah hal penentu kemajuan suatu bangsa. Akan tetapi, karakterlah yang membuat suatu bangsa menjadi besar dan maju. Proses pembentukan karakter yang dilakukan oleh Nabi tidak hanya berupa transmisi konsep akan tetapi langsug dicontohkan oleh beliau sepanjang hidupnya. Nabi tidak hanya mengajarkan para sahabatnya apa itu baik atau buruk, akan tetapi beliau langsung mencontohkan sendiri mana yang patut dilakukan dan mana yang tidak. Sehingga nilai-nilai karakter tersebut bisa tertanam kuat dalam diri para sahabatnya bahkan hingga generasi-generasi setelahnya.

Dalam konteks pendidikan formal, maka peran serta guru sangat dibutuhkan di sini. Guru harus seperti Nabi yang tidak hanya mengajarkan nilai-nilai karakter. Akan tetapi membelajarkan, membimbing, dan mendampingi peserta didiknya untuk mengamalkan apa yang telah dipelajari. Sehingga posisi guru bukan hanya sebagai pengajar tetapi juga sebagai role model bagi peserta didik.

\section{Tahapan Pendidikan Karakter}

Proses penanaman karakter tidak semudah membalikkan telapak tangan. Namun butuh proses dan waktu. Pendekatan dalam pelaksanaan pendidikan karakter di sekolah harus dilakukan secara menyeluruh dan kontekstual. Pendidikan karakter di sekolah didasari oleh sebuah kebutuhan dengan mengikuti kebutuhan perkembangan zaman. Pelaksanaan pendidikan karakter ini dibangun dengan tiga pilar pijakan, yaitu; pertama, visi, misi, dan tujuan sekolah sebagai landasan yang paling kuat; kedua, komitmen, motivasi, dan kebersamaan, sebagai landasan berikutnya; dan ketiga, adanya tiga pilar yang ditegakkan secara bersama, yaitu; membangun watak, kepribadian, atau moral, mengembangkan kecerdasan majemuk, dan kebermaknaan pembelajaran. Ketiga pilar pijakan ini harus

\footnotetext{
5 Akhmad Muwafik Saleh, Pendidikan Karakter dalam Perspektif Spiritual, (Malang: Aditya Media Publishing, 2012), 1-2
} 
bersinergi bersama sehingga tercipta lingkungan sekolah yang berpendidikan karakter dan menghasilkan lulusan yang berkarakter pula. ${ }^{6}$

Ridwan menjelaskan ada tiga hal pembentukan karakter yang perlu diintegrasikan yaitu: ${ }^{7}$

a. Knowing the good, artinya anak mengerti baik dan buruk, mengerti tindakan yang harus diambil dan mampu memberikan prioritas hal-hal yang baik. Membentuk karakter anak tidak hanya sekedar tahu mengenai hal-hal yang baik, namun mereka harus dapat memahami kenapa perlu melakukan hal tersebut.

b. Feeling the good, artinya anak mempunyai kecintaan terhadap kebajikan dan membenci perbuatan buruk. Konsep ini mencoba membangkitkan rasa cinta anak untuk melakukan perbuatan baik. Pada tahap ini anak dilatih untuk merasakan efek dari perbuatan baik yang dia lakukan. Sehingga jika kecintaan ini sudah tertanam maka hal ini akan menjadi kekuatan yang luar biasa dari dalam diri anak untuk melakukan kebaikan dan mengurangi perbuatan negatif.

c. Active the good, artinya anak mampu melakukan kebajikan dan terbiasa melakukannya. Pada tahap ini anak dilatih untuk melakukan perbuatan baik, sebab tanpa anak melakukan apa yang sudah diketahui atau dirasakan akan ada artinya.

\section{Pendidikan Karakter di Pesantren}

\section{Falsafah Pendidikan di Pesantren}

Pembicaraan tentang pendidikan Islam di Indonesia maka tidak akan lepas dari pembicaraan tentang pesantren. Hal ini karena eksistensi pesantren di Indonesia telah berperan besar dalam mengawal perkembangan pendidikan di Indonesia. Bahkan, pesantren juga berandil besar membebaskan bangsa ini dari kejamnya feodalisme Belanda dan Jepang. Jasa besar pesantren tersebut terwujud dikarenakan kuatnya rasa nasionalisme dan cinta tanah air para Kyai dan santrinya. Meskipun dalam dekade terakhir ini muncul pandangan skeptis terhadap peran,

\footnotetext{
${ }^{6}$ Marjuni, "Pilar-pilar Pendidikan Karakter Dalam Konteks Keislaman”, dalam Auladuna, Vol. 2 No. 1, Juni 2015

${ }^{7}$ Ridwan, Muhamad. "Menyemai Benih Karakter Anak" dalam http://www.adzzikro.com/20120/ diakses tanggal 15 Nopember 2017
} 
fungsi, relevansi dan jaminan masa depan lulusan pesantren. Namun pesantren tetap mampu mempertahankan eksistensinya sebagai garda terdepan penjaga moralitas bangsa.

Kata pesantren berasal dari kata santri yang diberi awalan "pe" dan akhiran “an" yang dikarenakan pengucapan kata itu kemudian berubah menjadi terbaca “en" (pesantren), yaitu sebutan untuk bangunan fisik atau asrama di mana para santri bertempat. Tempat itu dalam bahasa Jawa dikatakan pondok atau pemondokan. Adapun kata santri sendiri berasal dari kata cantrik, yang berarti murid dari seorang resi yang juga biasanya menetap dalam satu tempat yang dinamakan dengan padepokan. Pesantren mempunyai persamaan dengan padepokan dalam beberapa hal, yakni adanya murid (cantrik dan santri), adanya guru (kiai dan resi), adanya bangunan (pesantren dan padepokan), dan terakhir adanya kegiatan belajar mengajar. ${ }^{8}$

Pondok pesantren pertama kali di Indonesia dan di Jawa tepatnya di desa Gapura, Gresik didirikan oleh Syekh Maulana Malik Ibrahim pada abad XV Masehi, yang berasal dari Gujarat, India. Pesantren mempunyai fungsi penting sebagai pusat pendidikan dan penyiaran agama Islam. Maulana Malik Ibrahim mendidik sejumlah santri yang ditampung dan tinggal bersama dalam rumahnya di Gresik. $^{9}$

Dalam tradisi pesantren, selain diajarkan mengaji dan mengkaji ilmu agama, para santri diajarkan pula mengamalkan serta bertanggung jawab atas apa yang telah dipelajari. Pesantren juga mengajarkan nilai-nilai kesederhanaan, kemandirian, semangat kerja sama, solidaritas, dan keikhlasan. Kesederhanaan menunjukkan pengunduran diri dari ikatan-ikatan dan hirarki-hirarki masyarakat setempat, dan pencarian suatu makna kehidupan yang lebih dalam yang terkandung dalam hubungan-hubungan sosial. Semangat kerja sama dan solidaritas pada akhirnya mewujudkan hasrat untuk melakukan peleburan pribadi ke dalam suatu

\footnotetext{
${ }^{8}$ Ahmad Muhakamurrohman, "Pesantren: Santri, Kiai, dan Tradisi", dalam $I b d a$ ', Vol. 12, No. 2, JuliDesember 2014

${ }^{9}$ M. Shodiq, "Pesantren dan Perubahan Sosial", dalam JURNAL FALASIFA. Vol. 2 No. 2 September 2011.
} 
masyarakat majemuk yang tujuannya adalah ikhlas mengejar hakikat hidup. Adapun dari konsep keikhlasan atau pengabdian tanpa memperhitungkan untung rugi pribadi itu terjelmalah makna hubungan baik yang bukan hanya antarsantri sendiri, tapi juga antara para santri dengan kiai serta dengan masyarakat. Dari spirit keikhlasan itu, menjadikan para alumni pesantren sebagai pribadi yang pintar secara emosional, berbudi luhur, serta bertanggung jawab terhadap setiap amanah yang diembannya. ${ }^{10}$

\section{Strategi Pembentukan Karakter di Pesantren}

Dalam membentuk sikap dan perilaku peserta didik yang baik, perlu diajarkan nilai-nilai yang sesuai dengan ajaran Islam dan norma yang berlaku di masyarakat. Nilai-nilai yang diajarkan adalah ketakwaan, keteladanan, kejujuran, kesederhanaan, keikhlasan, dan kesabaran. Nilai-nilai tersebut dianggap penting untuk diajarkan karena merupakan pondasi dalam pembentukan karakter anak sebagai bekal dalam menghadapi permasalahan terutama di era globalisasi ini. ${ }^{11}$

Menurut Bakri, dalam menginternalisasikan nilai-nilai dan membangun karakter baik pada ranah pribadi maupun sosial/kebangsaan, masing-masing pesantren memiliki ciri khas sendiri, tetapi juga memiliki beberapa kesamaan. Berikut akan diuraikan sebelas metode yang digunakan mayoritas pesantren untuk mencapai target pembentukan karakter para santri. ${ }^{12}$

a) Pengajian Kitab Kuning

Metode ini merupakan metode yang umum digunakan oleh pesantren untuk mentransmisikan nilai dan membangun karakter. Adapun metode pembelajaran yang jama' digunakan adalah metode sorogan dan metode bandongan $^{13}$. Kitab kuning merupakan simbol tradisi intelektual di kalangan

\footnotetext{
${ }^{10}$ Ahmad Muhakamurrohman, "Pesantren: Santri, Kiai, dan Tradisi”, dalam Ibda', Vol. 12, No. 2, JuliDesember 2014

${ }^{11}$ Mujtahidin dan Badrud Tamam, "Pendidikan Karakter Berbasis Pesantren di SD Al Mujtamak Pamekasan”, Widyagogik, Vol. 1, No.1, Januari-Juni 2013, 45-69

${ }^{12}$ Masykuri Bakri, Membumikan Nilai , 63

${ }^{13}$ Metode sorogan dilakukan dengan cara santri secara bergantian membaca kitab kuning di hadapan Kyai, dan sang Kyai langsung menyaksikan keabsahan bacaan santri, baik dalam konteks makna maupun bahasa (nahwu dan shorof). Sedangkan metode bandongan santri secara kolektif mendengarkan bacaan dan penjelasan sang Kyai sambil masing-masing memberi catatan pada kitabnya.
} 
pesantren. Melalui pengkajian kitab kuning para Kyai tidak hanya membekali santri dengan ilmu-ilmu grammar Arab (nahwu dan shorof) akan tetapi juga menginternalisasikan nilai-nilai karakter luhur yang dirumuskan oleh ulamaulama sholeh pengarang kitab kuning (di dunia pesantren disebut mu'asis).

b) Keteladanan Kyai dan Ustadz

Kyai menjadi role model yang diteladani berbagai aspek kehidupan dan kepribadiannya. Tindak-tanduk Kyai senantiasa menjadi sorotan bagi seluruh warga pesantren. Di samping sebagai penggerak dan pusat roda kehidupan pesantren, Kyai juga senantiasa harus menjadi suri tauladan bagi seluruh warga pesantren.

c) Latihan Spiritual (Riyadhoh)

Untuk membangun karakter di kalangan santri, dikembangkan model-model pembiasaan disiplin spiritual atau yang disebut dengan istilah Riyadhoh. Mulai dari sholat wajib berjamaah, aneka sholat sunnah seperti sholat dhuha dan tahajud, puasa, tilawah Al-Qur'an, dan wirid.

d) Pembiasaan pola hidup

Pada umumnya pesantren menggunakan pembiasaan pola hidup untuk membentuk karakter. Pola hidup ini biasanya dijadwal mulai santri bangun tidur sampai tidur lagi.

e) Pendisiplinan

Pendisiplinan di pesantren menggunakan metode reward dan punishment. Reward atau hadiah diberikan kepada santri yang berprestasi baik berupa barang maupun uang. Sedangkan punishment diberikan kepada santri yang melanggar tata tertib pondok. Berat ringannya hukuman tergantung pada seberapa berat pelanggaran yang dilakukan.

f) Mendidik melalui Berorganisasi

Beberapa model pendidikan karakter santri melalui organisasi adalah dengan dibentuknya; (1) organisasi pesantren, kepengusuran organisasi ini biasanya diisi oleh santri senior yang bertugas sebagai kepanjangan tangan Kyai untuk mengurus manajemen pesantren, dan (2) organisasi daerah 
yang dijadikan sebagai sarana berdemokrasi, berkomunikasi, bersillaturrahim, berinteraksi, mengembangkan sistem manajemen organisasi.

g) Mendidik Melalui Ibrah (Mengambil Pelajaran)

Motode ini dilakukan melalui penyampaian kisah-kisah religius, fenomena alam, dan peristiwa-peristiwa penting yang terjadi baik pada masa lalu maupun sekarang yang bisa diambil ibrahnya oleh para santri.

h) Mendidik melalui Mauidzah (nasehat)

Menurut Bakri, metode mauidzah harus mengandung tiga unsur, yakni: (a) uraian tentang kebaikan dan kebenaran yang harus dilakukan oleh seseorang dalam hal ini santri, misalnya tentang sopan santun, harus berjamaah dalam sholat, dan rajin dalam beramal; (b) motivasi dalam melakukan kebaikan; (c) peringatan tentang dosa atau bahaya yang bakal muncul dari adanya larangan bagi dirinya sendiri maupun orang lain.

i) Kepanduan (Pramuka)

Gerakan Pramuka adalah suatu gerakan pendidikan untuk kaum muda, yang bersifat sukarela, nonpolitik, terbuka untuk semua, tanpa membedakan asal-usul, ras, suku dan agama dengan menyelenggarakan kepramukaan melalui suatu sistem nilai yang didasarkan pada Satya dan Dharma Pramuka. Melalui pramuka, santri digembleng agar menjadi manusia yang berwatak dan berbudi pekerti luhur, yang beriman dan bertaqwa kepada Tuhan Yang Maha Esa, kuat mental, dan tinggi moral.

j) Olah Raga

Olah raga juga menjadi sarana pengembangan karakter di pesantren. Di dalam kode far play olah raga, terkandung makna bahwa pertandingan olah raga haruslah dijiwai dengan semangat kejujuran dan tunduk aturan. Menurut Bakri, dalam olah raga juga terkandung dimensi nilai perilaku positif multidimensional, seperti sikap sportif dan kejujuran, saling mendukung dan membantu, saling berbagi, kerja sama, saling percaya, dan kompak. 
k) Ilmu Kanuragan

Menurut Bakri, pengembangan karakter di pesantren juga dilakukan melalui kegiatan pengembangan ilmu kanuragan (pencak silat) yang mengintegrasikan unsur olah raga dan unsur kebatinan melalui pendekatan olah nafas. Melalui pencak silat santri selain digembleng secara fisik, mereka juga dididik untuk memiliki mental-spiritual yang kuat. Selain itu, dalam pencak silat para santri juga belajar tentang keorganisasian dan kaderisasi.

\section{Model Implementasi Pendidikan Karakter Berbasis Pesantren di Madrasah}

Kebijakan pemerintah melalui Kementerian Pendidikan dan Kebudayaan (Kemendikbud) mengenai pendidikan karakter dalam Kurikulum 2013 perlu disambut gembira dan didukung semua pihak. Pendidikan karakter mutlak diperlukan oleh setiap bangsa jika ingin menjadi bangsa yang beradab. Sejarah dan fakta membuktikan bahwa bangsa-bangsa yang maju bukan disebabkan bangsa tersebut memiliki sumber daya alam yang berlimpah, melainkan bangsa yang memiliki karakter unggul seperti kejujuran, kerja keras, tanggung jawab dan lainnya.

Madrasah sebagai lembaga pendidikan Islam yang memadukan antara ilmu pengetahuan dan pendidikan spiritual semestinya mampu menghasilkan lulusan-lulusan yang memiliki ciri khas yang berbeda dengan sekolah umum. Lulusan madrasah idealnya adalah manusia yang matang secara profesional dan spiritual. Namun dalam realitanya, lulusan madrasah tidak jauh berbeda dengan lulusan lembaga pendidikan umum. Ciri khusus lulusan madrasah belum tampak secara signifikan. Maka dari itu, madrasah membutuhkan metode yang efektif dalam meningkatkan kualitas lulusannya. Satu di antara alternatif solusi adalah dengan mengadaptasi strategi pendidikan karakter yang dilakukan oleh pesantren.

Langkah ini tentu bukanlah hal yang sulit dan mustahil bagi madrasah, mengingat semua modal yang dibutuhkan untuk menerapkan pendidikan karakter berbasis pesantren telah dimiliki madrasah. Mulai dari Islam sebagai landasan dasar, guru, peserta didik, sarana dan prasaran, visi, misi, tujuan, lingkungan dan budaya yang 
religius, kurikulum, dan bahan ajar. Dengan menerapkan pendidikan karakter berbasis pesantren, citra madrasah sebagai lembaga pendidikan Islam formal akan semakin kuat. Lebih dari itu, lulusan madrasah akan benar-benar menjadi representasi "produk" pendidikan Islam. Fauzan menuturkan, memadukan pendidikan formal dengan pesantren akan melahirkan kekuatan pendidikan yang mampu menghasilkan generasi yang berkarakter yang mencakup kecerdasan intelektual, emosional, dan spiritual. ${ }^{14}$

Mengacu pada Kerangka Acuan Pendidikan Karakter Kementerian Pendidikan Nasional Tahun 2010, secara prinsipil, pengembangan karakter tidak dimasukkan sebagai pokok bahasan tetapi terintegrasi kedalam mata pelajaran, pengembangan diri dan budaya satuan pendidikan. Oleh karena itu pendidik dan satuan pendidikan perlu mengintegrasikan nilai-nilai yang dikembangkan dalam pendidikan karakter ke dalam Kurikulum, silabus yang sudah ada. Prinsip pembelajaran yang digunakan dalam pengembangan pendidikan karakter mengusahakan agar peserta didik mengenal dan menerima nilai-nilai karakter sebagai milik peserta didik dan bertanggung jawab atas keputusan yang diambilnya melalui tahapan mengenal pilihan, menilai pilihan, menentukan pendirian, dan selanjutnya menjadikan suatu nilai sesuai dengan keyakinan diri. Dengan prinsip ini peserta didik belajar melalui proses berpikir, bersikap, dan berbuat. Ketiga proses ini dimaksudkan untuk mengembangkan kemampuan peserta didik dalam melakukan kegiatan sosial dan mendorong peserta didik untuk melihat diri sendiri sebagai makhluk sosial. ${ }^{15}$

Untuk menerapkan strategi pendidikan karakter pesantren, perlu diperhatikan prinsip-prinsip sebagai berikut:

\section{Berkelanjutan}

Proses pembangunan karakter harus dilakukan secara sistematis dengan model pendidikan holistik menggunakan metode knowing the good, feeling the good, dan acting the good. Knowing the good mudah diajarkan karena hanya pengetahuan bersifat kognitif saja. Pada tahap ini peserta didik dikenalkan dengan

\footnotetext{
${ }^{14}$ Fauzan, "Pendidikan Karakter Berbasis Pesantren: Studi Kasus Di Smp Puncak Darus Salam Pamekasan", Empirisma, Vol. 24 No.2 (Juli, 2015), 277

${ }^{15}$ Direktorat Ketenagaan, Kerangka Acuan Pendidikan Karakter Tahun Anggaran 2010, (Kementerian Pendidikan Nasional, 2010), 11
} 
karakter-karakter yang ingin dikembangkan. Setelah itu ditumbuhkan feeling loving the good, yakni bagaimana merasakan dan mencintai kebajikan. Sehingga peserta didik senantiasa mau berbuat suatu kebaikan dengan senang hati tanpa ada paksaan. Setelah terbiasa melakukan kebajikan, maka acting the good itu berubah menjadi kebiasaan dan menjadi bagian dari diri peserta didik.

\section{Partisipatif}

Pembangunan karakter tidak akan berjalan efektif tanpa adanya peran serta peserta didik. Hal ini karena dalam paradigma pendidikan, peserta didik merupakan pusat dari proses belajar mengajar (student centered). Maka konsekuensinya, penyusunan program pendidikan karakter harus memprioritaskan keterlibatan peserta didik

\section{Menyenangkan}

Prinsip ini menyatakan bahwa proses pendidikan karakter dilakukan oleh peserta didik bukan oleh pendidik. Pendidik menerapkan prinsip "tut wuri handayani" dalam setiap perilaku yang ditunjukkan peserta didik. Prinsip ini juga menyatakan bahwa proses pendidikan dilakukan dalam suasana belajar yang menimbulkan rasa senang dan tidak indoktrinatif. Diawali dengan perkenalan terhadap pengertian nilai yang dikembangkan maka pendidik menuntun peserta didik agar secara aktif (tanpa mengatakan kepada peserta didik bahwa mereka harus aktif tapi pendidik merencanakan kegiatan belajar yang menyebabkan peserta didik aktif merumuskan pertanyaan, mencari sumber informasi dan mengumpulkan informasi dari sumber, mengolah informasi yang sudah dimiliki, merekonstruksi data/fakta/nilai, menyajikan hasil rekonstruksi/proses pengembangan nilai) menumbuhkan nilai-nilai karakter pada diri peserta didik melalui berbagai kegiatan belajar yang terjadi di kelas, satuan pendidikan, dan tugas-tugas di luar satuan pendidikan. $^{16}$

Melalui pembelajaran yang menyenangkan, peserta didik tidak akan merasa terpaksa dalam menerapkan karakter yang dikembangkan. Sebaliknya, mereka

\footnotetext{
${ }^{16}$ Direktorat Ketenagaan, Kerangka Acuan Pendidikan Karakter Tahun Anggaran 2010, (Kementerian Pendidikan Nasional, 2010), 13
} 
justru akan mencintai dan senang pada nilai-nilai karakter yang ditanamkan tersebut.

Adapun pendekatan yang dapat digunakan dalam upaya membangun karakter peserta didik di madrasah dengan mengacu apa yang telah dilakukan oleh pesantren, maka dapat dirumuskan sebagai berikut:

\section{Keteladanan}

Keteladanan merupakan strategi utama pesantren dalam membangun karakter santrinya dengan Kyai sebagai role model-nya. Adapun dalam konteks madrasah maka jajaran pimpinan (kepala madrasah dan wakilnya), pendidik dan tenaga kependidikan berperan sebagai role model bagi seluruh peserta didiknya. Segala tindak-tanduk mereka harus mencerminkan karakter-karakter yang ingin ditanamkan dalam diri peserta didik. Guru di mata peserta didik sekolah dasar setidaknya memiliki enam peran, yaitu sebagai orangtua, pembimbing, pendidik, motivator, inspirator, dan fasilitator. Peran-peran ini tidak jauh berbeda dengan peran Kyai di pondok pesantren.

Pendemonstrasian berbagai contoh teladan merupakan langkah awal pembiasaan, jika pendidik dan tenaga kependidikan yang lain menghendaki agar peserta didik berperilaku dan bersikap sesuai dengan nilai-nilai karakter, maka pendidik dan tenaga kependidikan yang lain adalah orang yang pertama dan utama memberikan contoh bagaimana berperilaku dan bersikap sesuai dengan nilai-nilai terebut. $^{17}$

Mengenai keteladanan ini, Nabi Muhammad SAW sendiri telah mencontohkan sepanjang hidupnya. Dalam mendidik, membimbing, dan membangun karakter sahabatnya, Nabi senantiasa memberikan teladan tentang apa yang beliau ajarkan. Sehingga generasi sahabat dapat menjadi generasi terbaik sebagaimana dinyatakan sendiri oleh Nabi dalam hadits:

\footnotetext{
${ }^{17}$ Direktorat Ketenagaan, Kerangka Acuan Pendidikan Karakter Tahun Anggaran 2010, (Kementerian Pendidikan Nasional, 2010), 14
} 
"Sebaik-baik umatku adalah generasiku, lalu mereka yang datang setelahnya, kemudian mereka yang datang setelahnya.” (H.R. Bukhari dan Muslim). ${ }^{18}$

Dengan demikian, upaya peningkatan mutu guru harus dilakukan secara komprehensif dan menyentuh empat kompetensi wajib yang harus dimiliki guru, yaitu Pedagogik, Kepribadian, Sosial, dan Profesional.

\section{Pembiasaan}

Pembangunan karakter santri yang dilakukan oleh pesantren melalui pembiasaan sebagaimana diutarakan Bakri di atas membuktikan bahwa pembangunan karakter tidak bisa dilakukan dalam waktu singkat seperti halnya menghafal rumus atau konsep. Oleh sebab itu dibutuhkan proses pembiasaan yang kontinu dan ajeg (istiqomah). Jika dalam pesantren proses pembiasaan ini berlangsung selama dua puluh empat jam sehari, maka dalam konteks madrasah proses pembiasaan memiliki durasi yang lebih singkat yaitu enam sampai delapan jam sehari.

Waktu yang relatif singkat ini harus dimanfaatkan dengan baik oleh pendidik dan pengelola madrasah. Oleh karena itu perlu adanya instrumen terukur yang digunakan untuk menopang upaya pembangunan karakter ini. Instrumen ini dapat berupa pembudayaan nilai-nilai karakter yang ingin dikembangkan dalam semua aktivitas siswa selama di madrasah. Proses pembudayaan ini harus mengedepankan prinsip partisipatif, dimana peserta didik menjadi fokus utama. Misalnya program sholat berjama'ah, istighotsah, bersalaman setiap bertemu dengan guru dan sebagainya.

\section{Pendisiplinan}

Selama proses pembiasaan sebagaimana dipaparkan di atas, perlu ada proses pendisiplinan dengan menggunakan reward and punishment. Pendisiplinan ini tidak dimaksudkan sebagai paksaan terhadap peserta didik untuk berperilaku seperti yang diprogramkan. Namun pendisiplinan dimaksudkan untuk lebih mendorong peserta didik mencintai dan menyadari pentingnya nilai-nilai karakter. Reward dan

${ }^{18}$ Tim Aswaja NU Center PWNU Jawa Timur, Khazanah Aswaja, (Surabaya: Aswaja NU Center PWNU Jawa Timur, 2016), 195 
punishment harus dipahami sebagai pemicu motivasi dan pelecut semangat. Oleh sebab itu, pemberlakuan reward dan punishment harus memprioritaskan unsur pedagogiknya.

\section{Proses Belajar Mengajar}

Satu di antara problema klasik di dunia pendidikan kita adalah proses pembelajaran yang masih jauh dari realita kehidupan. Sebagai akibatnya, lulusan pendidikan kita belum bisa banyak "berbicara" di pentas persaingan global. Belum hadirnya dunia nyata dalam proses belajar mengajar ini diakibatkan oleh penggunaan pendekatan, strategi, metode, dan teknik pembelajaran yang monoton dan sentralistik. Selain itu, masih mengakarnya paradigma "guru sebagai satusatunya sumber pengetahuan" turut menjadi biang keladi masalah ini. Agar proses pendidikan karakter berjalan efektif, permasalahan dan paradigma tersebut harus segera diatasi.

Pembelajaran berbasis karakter harus dilaksanakan secara kontekstual bukan tekstual. Artinya, guru harus memberikan porsi lebih besar pada penghadiran realitas kehidupan di dalam kelas dibandingkan dengan paparan konsep semata. Selain itu, peran guru dalam pembelajaran berbasis karakter bukan hanya sebatas mentransmisikan pengetahuan akan tetapi sebagai fasilitator dan motivator bagi peserta didik dalam mengamalkan nilai-nilai yang telah dipelajari.

\section{Pengintegrasian dalam materi pelajaran}

Pengintegrasian nilai karakter dapat dilakukan untuk satu atau lebih dari setiap pokok bahasan dari setiap materi pembelajaran. Seperti halnya sikap, suatu nilai tidaklah berdiri sendiri, tetapi berbentuk kelompok. Secara internal setiap nilai mengandung elemen pikiran, perasaan, dan perilaku moral yang secara psikologis saling berinteraksi. Karakter terbentuk dari internalisasi nilai yang bersifat konsisten, artinya terdapat keselarasan antarelemen nilai. Sebagai contoh, karakter jujur, terbentuk dalam satu kesatuan utuh antara tahu makna jujur (apa dan mengapa jujur), mau bersikap jujur, dan berperilaku jujur. Karena setiap nilai berada dalam spektrum atau kelompok nilai-nilai, maka secara psikologis dan 
sosiokultural suatu nilai harus koheren dengan nilai lain dalam kelompoknya untuk membentuk karakter yang utuh. ${ }^{19}$

Oleh sebab itu, materi pendidikan karakter tidak berdiri sendiri dan diajarkan terpisah dengan mata pelajaran lainnya. Akan tetapi menjadi satu terintegrasi dalam semua materi pelajaran. Sebagaimana di pesantren, meskipun ada materi tentang akhlak semisal Kitab Akhlaqul lil baniin, namun di setiap proses pembelajaran (pengkajian kitab) selalu disisipkan pesan-pesan moral.

\section{E. Penutup}

Kemerosotan moral di kalangan remaja usia sekolah bukanlah suatu persoalan yang bisa ditunda pencarian solusinya. Karena hal ini menyangkut masa depan dan kualitas generasi penerus bangsa dan negara. Untuk mengatasi permasalahan ini, diperlukan adanya upaya yang holistik dan komprehensif serta keterlibatan semua pihak. Madrasah dalam hal ini juga menjadi pihak yang bertanggungjawab. Sebagai lembaga pendidikan yang berasaskan Islam, madrasah diharapkan mampu menghasilkan lulusan yang memiliki kematangan karakter bercirikan Islam. Satu di antara upaya untuk mewujudkan hal itu adalah dengan mengadopsi strategi pembangunan karakter yang telah dilakukan oleh pesantren. Strategi tersebut yakni melalui keteladanan sebagai basisnya, pembiasaan, pendisiplinan, proses belajar mengajar, dan pengintegrasian ke dalam semua materi pelajaran. Semua strategi tersebut harus berpegang pada prinsip berkelanjutan, partisipatif dan menyenangkan.

\section{F. Daftar Rujukan}

Bakri, Masykuri. Membumikan Nilai Karakter Berbasis Pesantren Belajar dari Best Practice Pendidikan Karakter Pesantren dan Kitab Kuning. Jakarta: Nirmana Media, 2011.

Direktorat Ketenagaan, Kerangka Acuan Pendidikan Karakter Tahun Anggaran 2010. Kementerian Pendidikan Nasional, 2010.

Fauzan. "Pendidikan Karakter Berbasis Pesantren: Studi Kasus Di Smp Puncak Darus Salam Pamekasan”. Empirisma. Vol. 24 No.2. Juli 2015.

\footnotetext{
${ }^{19}$ Direktorat Ketenagaan, Kerangka Acuan, 19
} 
Marjuni. "Pilar-pilar Pendidikan Karakter Dalam Konteks Keislaman". dalam Auladuna. Vol. 2 No. 1, Juni 2015.

Muhakamurrohman, Ahmad. "Pesantren: Santri, Kiai, dan Tradisi". Ibda'. Vol. 12, No. 2, Juli-Desember 2014

Mujtahidin dan Badrud Tamam. "Pendidikan Karakter Berbasis Pesantren di SD Al Mujtamak Pamekasan”. Widyagogik. Vol. 1, No.1. Januari-Juni 2013.

Ridwan, Muhamad. 2012. Menyemai Benih Karakter Anak. (online), http://www. adzzikro.com

Saleh, Akhmad Muwafik. Pendidikan Karakter dalam Perspektif Spiritual. Malang: Aditya Media Publishing, 2012.

Shodiq, M. "Pesantren dan Perubahan Sosial". JURNAL FALASIFA. Vol. 2 No. 2 September 2011.

Tim Aswaja NU Center PWNU Jawa Timur. Khazanah Aswaja. Surabaya: Aswaja NU Center PWNU Jawa Timur, 2016. 